\title{
GENDER IN CONTEMPORARY ITALIAN CONTEXT. A FOCUS ON INFORMAL EDUCATION AND PROPOSALS FOR A GENDER SENSITIVE APPROACH THROUGH INTERGENERATIONAL AND INTERCULTURAL DIMENSIONS
}

\section{Abstract}

Gender is a pervasive informal educational experience. This is particularly true in the Italian context, where the educational system, lacking an intentional gender education and a gender-sensitive approach, risks to contradict its most essential finalities: the promotion of equal opportunities and active citizenship. This paper, according with the transformative vocation of pedagogical research, explores the risks and opportunities of informal gender education. After a theoretical introduction, intergenerationality and interculturality are suggested as dimensions whose exploration facilitates a better understanding of the complexity of the contemporary gender order, opening up new possibilities to challenge it.

Keywords: Informal gender education, intentional gender education, intergenerational relationships, intercultural relationships.

\section{Resumo}

Questões de género no contexto italiano contemporâneo. Uma análise focada na educação informal e propostas para uma abordagem sensível ao género através de dimensões intergeracionais e interculturais

O género está presente de forma generalizada em todas as experiências de educação informal. Isto é particularmente verdadeiro no contexto italiano, em que o sistema educacional, sem uma educação intencional que aborde temáticas de género e faça uso de uma abordagem sensível ao género, corre o risco de não concretizar as suas finalidades fundamentais: a promoção da igualdade de oportunidades e a cidadania ativa. Este artigo, de acordo com a vocação transformadora da investigação pedagógica, explora os riscos e as oportunidades da educação informal sobre género. Depois de uma introdução teórica, sugere-se que intergeracionalidade e interculturalidade sejam dimensões cuja exploração

Department of Human Sciences for Education «Riccardo Massa», University of Milano-Bicocca, Italy

Electronic address: lisa.brambilla@unimib.it

Postal address: Università degli Studi di Milano-Bicocca, Piazza dell'Ateneo Nuovo, 1, 20126 Milano, Italia.

** Department of Human Sciences for Education «Riccardo Massa», University of Milano-Bicocca, Italy

Electronic address: giulia.pozzebon@unimib.it

Department of Human Sciences for Education «Riccardo Massa», University of Milano-Bicocca, Italy

Electronic address: m.rizzo8@campus.unimib.it 
facilita uma melhor compreensão da complexidade da ordem de género na atualidade, abrindo dessa forma novas possibilidades para desafiá-la.

Palavras-chave: Educação informal de género, educação intencional de género, relações intergeracionais, relações interculturais.

\section{Résumé}

Genre dans le contexte italien contemporain. Une analyse de l'éducation informelle et propositions pour une approche sensible au genre à travers les dimensions intergénérationnelles et interculturelles

Le genre est une expérience éducative principalement inintentionnelle, en particulier dans le contexte italien, où le système éducatif, en l'absence d'une éducation intentionnelle au genre et d'une approche sensible au genre, risque de contredire ses finalités essentielles: la promotion de la parité homme/femme et d'une citoyenneté pleine. Cet article, en accord avec la vocation transformative de la recherche pédagogique, explore les risques et les opportunités de l'éducation informelle de genre. Après une introduction théorique, l'intergénérationnalité et l'interculturalité sont suggérées en tant que dimensions dont l'exploration peut faciliter la compréhension de la complexité de l'ordre de genre actuel, et ouvrir la possibilité de le défier.

Mots clés: Éducation informelle au genre, éducation intentionnelle au genre, relations intergénérationnelles, relations interculturelles.

\section{Premises}

In the last years, informal education gained institutional recognition as a «learning resulting from daily life activities related to work, family or leisure [...] often referred to as experience based and [...] accidental learning». ${ }^{1}$ According to the Italian tradition of Social Pedagogy, which analyzes societal influence on men and women pathways of life and society's educational dimensions, it can be considered a «widespread, relational, not intentional, spontaneous, unconscious, territorial, social education» (Tramma 2009, 8). For educators it is important to be aware of this education, to recognize and judge its influences in order to act intentionally, supporting or discouraging it, especially considering its increased power in contemporary society (Tramma 2015).

Furthermore, considering gender as «something that one does; and does recurrently, in interaction with others» (West and Zimmerman 1987, 140), means to recognize it primarily as the result of a daily education. Although a theoretical attention to this kind of education arose in Italy almost 40 years ago, to this date, on a practical level, gender intentional education (Gamberi, Maio, and Selmi 2010) is missing inside both formal and non-formal educational contexts, and the gender dimension remains largely informal and underexplored.

\footnotetext{
1 «Promoting learning for the world of work», UNESCO-UNEVOC (2013).
} 
Taking this situation into account, the pedagogical field has clear educational responsibilities towards the upbringing of the new generations of girls and boys. It becomes an urgent task in Italy, where levels of gender gap and discrimination are still high and some social phenomena, such as femicide, homophobia, sexual violence and exploitation, represent an emergency (Ulivieri 2014).

Using the perspectives of Social Pedagogy and Gender Pedagogy, this paper aims at introducing a reflection on risks and opportunities of gender as a pervasive informal educational experience. After a theoretical framework, it tries to provide some more concrete examples of informal gender education in action, using the interpretative perspectives of intersectionality, intergenerationality and intercultural$i t y$. In conclusion, some opportunities to deal with it are suggested.

\section{Gender and education. The role of informal education}

At a theoretical level, in nowadays' Italy, the necessity to accompany the new generations to shaping and to becoming aware of their gender subjectivity is growing (Cagnolati, Minerva, and Ulivieri 2013). The purpose is to provide them with useful tools for the deconstruction of heteronimy and dependence that might help them recognize, support and enhance plural differences implied in the construction of gender (Gamberi, Maio, and Selmi 2010). Nevertheless, only few gender studies have entered academic field, particularly in educational faculties whose aim is to train new teachers and educators (Antonelli, Sarra, and Sorrentino 2013); furthermore, only few educational projects are specifically dedicated to disseminate gender intentional education. They are supported by the discontinuous financing of the non-profit sector and aren't recognized by the Italian Minister of Education as tools to redefine and update the school curriculum (Padoan and Sangiuliano 2008). These two elements jointly contribute to keep intentional education far away from the processes of gender socialization, leaving children, adolescents and young people alone in the difficult task of becoming themselves (De Luigi and Gobbi 2010; Albanesi and Lorenzini 2011). This is not the only problem facing a country troubled by the absence of a gender culture in public discourse (Simone 2011; Volpato 2013). Apart from few specific topics (e.g. violence against women, trafficking and exploitation), the wider area of educational services is lacking a gender-sensitive approach, in spite of the intersection between this dimension and other axes of oppression (Risman 2004) to which educational intervention is specifically designed (mental disease, disability, poverty etc.).

Educational projects and practices remain far from the processes informing gender learning and are limited to daily experiences (Brambilla 2016), defined by Social Pedagogy as informal or social education (Catarci 2013). Such experiences can be found not only outside but also, in much more problematic terms, inside formal and non-formal educational contexts. Unfortunately, attention to the gender 
dimension remains at a rather generic level, like an exhortation that, however, does not seem to have clear application and practical effects. Intentional education has been unable to adopt gender studies and to acknowledge the relevance of their contents (Crivellaro et al. 2013). As a useful category of analysis (Scott 1986), gender does not seem to be part of a shared epistemological heritage. In the whole educational context, for example, gender has hardly been considered as a critical tool, in synergy with others, for the analysis of users' needs, to determine educational objectives and plan and evaluate interventions beyond the social mandate and thus beyond common sense and public discourse.

Like a neutral lens, intentional education remains gender blind, becoming an accomplice in the persistence of a problematic and discriminating gender order. In spite of a greater awareness than in the past about the presence of a more complex gender system, educational contexts don't seem to be prepared to problematize systematically the dominant conceptualization about femininity and masculinity, their relationships and the oppressive effects of this link and to recognize male and female as the outcome of a social construction.

The naturalization of gender inequality - which still lies in gender culture, informally present in many educational services - produces a «naive biological determinism» (West and Zimmerman 1987, 129) that contributes to reproduce stereotypes, inequality, discrimination and becomes an occasion of normalization. Moreover, the recognition of cultural influence itself can be problematic without gender consciousness: its overweight consideration, if, on the one hand, seems to prevent from the temptation of emphasizing the aspect of «subjectivation» of social actions, as if the latter were suddenly freed from any boundary (Leccardi 2002, 49); on the other, leads to the underestimation of personal choice and self-determination. This seems to undermine and limit the possibility to consider the differences that characterize every single person as a premise for a possible educational opportunity to challenge the material and symbolic gender order. In defiance of first Queer philosophy's wishes (Butler 1999), recognizing contemporary complexity does not appear to have any automatic influence on the way professional educators consider and «do gender» (West and Zimmerman 1987, 125). A traditional and stereotypical conceptualization of the gender dimension lies in educational contexts and, even without permission, contributes to inform educational practices without any (or with low) consciousness about its effects. ${ }^{2}$

While in education there is agreement on certain finalities - such as the promotion of equality, freedom, self-determination and emancipation of every single subjectivity in order to promote an active and full citizenship -, equal opportunities risk to be systematically contradicted, not only by what people experiment in daily life, but also within the educational (formal and non-formal) contexts, which

The considerations in this paragraph arise from the preliminary results of a qualitative research titled «Gender cultures and perspective of intervention in educational services» that the first author of this article is conducting at the University of Milano-Bicocca. 
remain without a gender-sensitive approach. ${ }^{3}$ In spite of the long and international tradition of Critical pedagogy (Cambi 2009) and, in particular, the adoption of a Feminist perspective in the educational field - which arose in Italy in the 1970s (Leonelli 2011a, 1) - intentional education remains widely responsible for the ratification and reproduction of gender-based discriminations.

The widespread presence of all kinds of informal education within the intentional educational contexts is unavoidable (Tramma 2009). This could not only be a risk and a contradiction but also, at the same time, an opportunity for pedagogical aims. In this sense, as shown above, informal gender education could stimulate the reproduction of the disadvantageous gender order implicitly embedded in educational practices as a parallel «pedagogical discourse» (Pasolini 1976, 35). Where recognized and deconstructed, this form of education could be also a generative teaching and learning resource, useful at a theoretical, practical and political level. As the critical analysis on the education showed - see among others Lorenzo Milani or Pierre Bourdieu and Jean Claude Passeron -, questioning the continuity between pedagogical knowledge, educational practices and the conservative status quo is possible. In particular, some feminist pedagogues signed a turning point by exploring and deconstructing (explicit and implicit) gender matrixes of the history of pupils' education, revealing for the first time the existence of a Pedagogy of ignorance (Ulivieri 2001, 14) targeted at girls, and the female teachers' key role in preserving and reinforcing it.

In contemporary Italy, progress goes hand in hand with old and new forms of gender asymmetry, discrimination and exclusion (both material and symbolic), therefore it can't be reasonably assumed that the diffusion of a gender gaze in the educational sector is only a question of time and that it will happen automatically; meanwhile, in fact, this gaze remains delegated to a small minority of gender sensible practitioners. ${ }^{4}$ Alongside the implementation of ad hoc academic training, a useful way to implement this kind of approach in education should ground on a transformative learning (Mezirow 1991) supplemented by a gender theoretical framework that allows practitioners to recognize and analyze where, «under what conditions and how gender inequality is being produced» (Risman 2004, 435) in both intentional and informal educational contexts and practices, focusing at the same time on those experiences in which gender provides an opportunity to express freedom and agency. This means not only to identify educational needs and problems and respond with preventive and rehabilitative interventions, but also to recognize positive gender educational experiences so as to support and enhance them.

In contemporary society, the reproduction, transformation and dialogue among different gender models and cultures take place across several dimensions; among them, vertical relationships between generations and horizontal relation-

As in the cases of gender segregation or hidden curriculum.

See www.scosse.org

ex æquo, n. ${ }^{\circ}$ 36, 2017, pp. 133-148. DOI: https://doi.org/10.22355/exaequo.2017.36.08 
ships between people with different cultural backgrounds are particularly meaningful from an educational viewpoint. The exploration of the educational risks and opportunities along these two axes is possible by adopting intergenerationality and interculturality as interpretative perspectives. The following paragraphs are dedicated to examining these opportunities.

\section{Vertical axis: intergenerational relationships ${ }^{5}$}

\section{Intergenerational perspective}

We can observe that people's gender learning tends to occur informally and unconsciously (Brambilla 2016) by adopting a vertical axis, which focuses on intergenerational relationships, where two different forces coexist:

- a centrifugal force, representing the capability of social systems (family, organizations, institutions etc.) to influence the generations within them; their members will base their lifestyle in society on these previous learnings;

- a centripetal force, considering generations as a group of cohorts, who express their identities in relation to social spaces and times. This way, each generation is influenced by the broader historical-economic-cultural context and outlines women and men's biographies as subjective stories and, at the same time, as collective and generational ones (Kehily 2008).

Intergenerational relationships are very important for the self-definition of young people as women or men. However, currently adults are affected by a «crisis of anteriority» (Palmieri 2012, 93-94), that makes them hardly credible and rewarding models. This situation creates an impasse in the intergenerational pact that regulates cultural transmission - also about gender - among generations and opens up ambiguities: while there are a greater number of new opportunities for self-definition than in the past, it is as probable that the new generations feel disoriented and react with some adaptive or defensive responses. This situation implies some educational problems and opportunities.

\section{Relationships with adults in families}

In the Italian inhomogeneous socioeconomic context, risks and occasions are linked to the specific resources of every family: some families only include one

The considerations in this section arise from the preliminary results of a qualitative research titled «Educational feminine paths and generational passages» that the third author of this article is conducting at the University of Milano-Bicocca. 
member, in others, different generations live side by side and being a parent is not something in opposition to being a child. Different models of femininity and masculinity coexist and can be, explicitly or not, in conflict. This combination can push the new generations to adhere to the «already given» or to reject it unawarely.

Considering family culture as something that is plural and that establishes limits and opportunities in biographies - even around gender and generational belongings (Saraceno and Naldini 2013) - means to recognize intersectionality as a fundamental interpretative and operative tool (Collins and Bilge 2016). The femininity and masculinity messages for the new generations are, in fact, linked to the different relationships, roles, tasks and responsibilities that are experienced within the family. These messages also depend on personal gender and generational belongings, and on the coexistence of generations that have experienced different social spaces and times and, sometimes, several geographic horizons. Moreover, these messages are linked to the opportunities of self-definition that are legitimized or discouraged by family culture and with its capacity to re-read, revise and put in dialogue these multiple learnings. This skill should be supported by the educational system.

Consequently, family becomes a strong «matrix of identity» (Formenti 2003, 51-64), where identicalness and subjectivity are played, not always in a painless way, in a system of ties and opportunities that has already been set. Gender and generational belongings end up selecting the range of expectations that adults feed on young people, who translate these expectations into personal aims: an external «have has to be» becomes an internal self-imposed one. Gender is a social and subjective construct that everyone uses to the one's self-definition, starting from relationships, restrictions and opportunities lived and internalized (consciously or not) in the family.

In this frame, intergenerational negotiation is a fundamental concept (Tarrant 2010) marked by ambiguity: on the one hand, we recognize the importance of the family, but on the other hand the family itself can be seen as a historical and symbolic space in which sexual difference remains a «social destiny». The crisis of strong narratives, which have characterized modernity and the previous generations, opens up to the possibility to creatively explore oneself and the world, shaping fluid identities linked to multiple points of reference (Hopkins and Pain 2007). However, a lack of orientation in making choices may lead to adhere unconsciously to stronger, traditional models and messages accessible in the local and familial contexts. The risk is that self-definition happens in a solitary way, floating between unaware adaptation and rebellion to the status quo. Between these (apparent) polarities, there are people aware of their gender learning, but who can't live in another way; and it must be noticed that the burden of the social role is particularly heavy on women's shoulders. Indeed, despite new possibilities of self-definition and the presence of plural gender models, it is still difficult to propose alternative gender messages (Callari Galli 1988), without a concrete support 
of educational intervention. While the Internet and other media, but also Catholic culture - that is particularly relevant in the Italian context (Murgia 2011) -, propose high ideals and inaccessible and often frustrating myths (especially for women), institutions and intentional educational contexts lose attractiveness and pass the baton to families, with their gender models, often traditional, anachronistic and unaware.

This complexity questions pedagogy, which could provide the epistemological tools to identify risks and potentials of informal education.

\section{Relationships with adults in educational contexts: school and oratorio}

Schools and Catholic youth centers (called oratorio) are publicly acknowledged and very important in Italy for the new generations' growing process (Acerbi and Rizzo 2016). Schools are mainly secular and public, while oratori are private and confessional and offer young people widespread and free occasions to meet. The crisis of the welfare state (Tramma 2015) and of intentional education seems to pass on greater educational responsibilities to oratori, designed as voluntary (and not professional) places, but with a strong educational mission. In addition, to this date, schools and oratori have not managed to plan their own intentional gender education proposal. Such situation contributes to perpetuate a female education «to do» and not «to think», and an ideology of neutrality of knowledge, which doesn't encourage young girls and boys to recognize their own differences and to dialogue with others' differences.

In this frame, explicating the personal point of view can favor intergenerational dialogue and personal responsibility, thanks to the fact that the subject thinks himself/herself and the world starting from his/her personal difference (Papucci 2010). This process of explicating enables educators to take action with girls and boys, perceiving them not as indistinct receivers but as sexual bodies with personal and unique stories that bring with them different social-cultural models. Furthermore, it becomes possible to take action with adults by encouraging them to re-elaborate gender practices and models, activated in formal and non-formal contexts and often proposed unawarely. Indeed, teaching/educational staff are is often affected by gender segregation: care and relations remain female responsibilities, while power and control, personified by leadership, direction and knowledge, are male privileges, with a female collusion (Volpato 2013). Women, in fact, perceive themselves as neutral and banal in their educational roles and functions, particularly when they work with young children (Guerrini 2017). In this sense, it seems crucial to accompany adults to develop their awareness about the consequences of inequalities, segregation of skills, knowledges, roles and functions. The re-elaboration of one's sexual position and sceneries can stimulate a new and more aware adult educational direction and can contribute to establish coed- 
ucation and gender reciprocity, valorizing the new generations. This way, child identity can be seen as a desire and not as a destiny.

Schools and oratori, in this way, could come back to be privileged contexts, places where there are real opportunities to experiment alternative meetings, encountering increasingly multiple differences, with different familiar, generational and personal cultures and traditions, and their different gender models. So, if these contexts were able to empower their own democratic side, starting by adult formation, they could inspire a renewal not only of vertical and intergenerational relationships but also of horizontal ones. They could go beyond the anachronistic educational approaches, the segregation of gender knowledges and roles, and the mistrust and fear towards difference.

\section{Horizontal axis: intercultural relationships ${ }^{6}$}

\section{Interculturality in the Italian context}

One of the most evident transformations of contemporary society is the growing multiculturalization of physical, virtual and symbolic territories of life. In a season that has been defined as «the Age of Migration» (Castles et al. 2013), some theories even postulate the advent of a post-multicultural society, particularly within the metropolises of the Western world, characterized by super-diversity and transnationalism (Crul, Lelie and Schneider 2013).

During the last century, migration flows completely changed Italian social environment. After a long period of strong emigration of native population, two important migration movements took place: the first one (1950-1970) was internal and involved a consistent part of the Italian population moving from rural areas of South, Central and North Eastern Italy to the industrialised North West (these migrants are now at the third generation). Around the 1980s, the decrease of these national flows was replaced by the simultaneous start of immigration. At the beginning, migrants towards Italy were predominantly temporary single workers, male and female, but, with the advent of the new millennium, foreign people residing in the country have been joined by their relatives, and immigrant population becomes more stable. Recently, an increasing number of migrants mostly refugees and asylum seekers - arrived from what is known as the Mediterranean Route of migration. As a consequence of the actual geopolitical events, in less than 20 years Italy became one of the most important receiving countries in Europe, with an immigrant population coming from many different areas (Ambrosini 2011).

The considerations in this section arise from the preliminary results of a qualitative research titled «Daughters of immigration: mixed biographies among gender-based and intercultural dynamics» that the second author of this article is conducting at the University of Milano-Bicocca. 
When considering both internal and international migrants, Italy - North in particular - can be regarded as a strongly multicultural context, where people with extremely different ethnic and cultural backgrounds meet each other and live side by side: it is difficult to identify a shared cultural tradition in a context that appears culturally disjointed, mixed and miscellaneous.

\section{Gender, intercultural relationships and informal education}

From a pedagogical point of view, this coexistence of various cultural traditions is interesting for the informal educational contributions that they offer to new generations (Berry 2006), due to the interconnection among several gender models, proposed implicitly, constantly and concurrently (Okin et al. 1999; Campani 2010). Taking this heterogeneity into account implies the identification of a second axis through which gender informal education develops: a horizontal axis, traceable in the daily relationships between people with different cultural backgrounds. As intergenerational relationships, also intercultural ones affect people's daily life: throughout the public spaces of our multicultural cities, inside families, within the peer group, in virtual life and even inside and outside educational services.

This awareness prompted some intercultural pedagogues to argue that the experience of interculturality of the new generations of boys and girls is qualitatively different from the past: new generations are defined as intercultural natives (Granata 2015), born in a multicultural world and «naturally» ready to the meeting with «the Other». The encounter of different cultures can provide those who experience it daily and constantly with an implicit incitement to reflect around what, inside a tradition, is «taken for granted». Furthermore, the interplay of a variety of gender models can enhance the reflection about what is «naturally» ascribed to a man or a woman in each cultural tradition (Feliciano and Rumbaut 2005). In boys and girls, this reflection may lead to a greater awareness about the cultural influence on their gender development, sustaining and encouraging their freedom and independence in making choices about their gender identities. In other words, the cultural heterogeneity could inspire young boys and girls to question and critically reconsider «traditional» gender models. This way, they could more awarely choose either adherence to or rejection of these models; a choice that could impact educationally their life.

Such awareness and freedom is not always fair and clear, particularly when concerning gender issues: one of the most widespread social phenomena in Italy (as in Europe) is related to the conflict which may explode within migrant families when a member refuses traditional gender models choosing, instead, to adhere to a more «occidental» one or, facing this complexity, decides to embrace strict versions of his/her tradition (Buccoliero 2012). Even without focusing on sensational - but, 
fortunately, marginal - stories of young girls running away from forced marriages, homosexual boys rejected by their families, or various forms of radicalization, an unavoidable question is about the relation between racialized gender models within migrant families and those diffused in the Italian society. These two models can be sometimes complementary, sometimes in open contradiction; in fact, people with a migration background should internalize - mainly unconsciously - at least two distinguished and racialized ways to perform gender: the first occurs when they are within their ethnic community, while the second is adopted when they are surrounded by natives. This skill to switch from a racialized femininity or masculinity to the other, modifying the gender performances in order to better fulfil the racialized gender norms, is part of the process of becoming men and women: youngsters with a migration background «grew up juggling different cultural expectations as they moved from home to school and often felt a pressure to behave differently» (Pyke and Johnson 2003, 37). This ability has been called shifting. If, on the one hand, it can be read as a big resource of adaptation and flexibility - useful skills in the complexity of contemporary word -, on the other hand, it can also be seen as a cause of pain and sufferance for people who hardly experiment integration, mostly when they are asked to choose between one or the other social and cultural belonging (Showunmi 2015). For that reason, it is suitable to educationally accompany migrant people in the construction of a complete and aware trans-racial gender identity, where both belongings are recognized and integrate each other reciprocally.

If the opportunity of translating cultural heterogeneity in a more aware and free gender choice is most evident for boys and girls with a migration background, meeting peers and adults who embody different gender models can enhance a reflection also in native Italian youngsters, showing how those models diffused in Italy are the outcome of a specific cultural tradition too.

\section{Gender, intercultural relationships and intentional education}

In the light of those shareable considerations, it is however necessary for the pedagogical field not to abdicate the responsibility that multiculturality conveys. Although new generations are more accustomed to the meeting with others, intercultural dialogue needs to be sustained by educational intentionality in order to spread all its potential (Reggio and Santerini 2014). Furthermore, cultural heterogeneity is growing not only across society, but also in formal and non-formal educational contexts, and practitioners cannot ignore this presence. For this reason, it is useful to reflect around dealing with interculturality and gender inside educational services and to introduce this reflection in teachers and educators' training. More than being necessarily gendered, in fact, the educational relationship between teachers/educators and users is also inevitably cultured (Reggio and San- 
terini 2014). This awareness forces the pedagogical field to question, renovate and update traditional models of intervention. In particular, it is needed for practitioners to develop greater consciousness around themselves as gendered and cultural subjects, who act and propose a model.

As intersectionality theory has clearly explained, the gendered and cultured positioning of two subjects (in this case, the teacher and the learner) influences, among other things, their relationship of power (Collins and Bilge 2016). Being aware of this model and its power doesn't mean to neglect it but, instead, to use it as a tool for educational aims. What does it mean for a North African young man with a strong sense of tradition to deal with an Italian woman with a social role more powerful than his? Or what does it imply for a young Chinese girl to obey or disobey to an Italian man?

Another important kind of awareness regards the possibility that gender and cultural model informally proposed by educators can be in conflict with those transmitted within families and/or ethnic communities. How to deal with this conflict, without discrediting the child's cultural tradition? How to accompany children with a migration background to juggling different cultural expectations? How to sustain them in finding a satisfying integration, in building a mixed identity that does not deny his/her multiple belongings? Those are fundamental questions for any professional engaged in this kind of relationship and cannot be ignored or postponed by pedagogical reflection.

\section{Conclusions}

Nowadays, in educational contexts, an attention to gender category is an unavoidable issue in order to sustain and promote the growth of the new generations as active citizens, not only in terms of equal gender opportunities but also to protect the differences, ambitions and desires of all subjects beyond gender binarism and heteronormativity. Gender attention should be widespread in the whole Italian educational system, from formal curriculum in schools to the training of professionals in higher education institutions.

Starting by a (new) gender sensitive educators' formation, it could be possible to favor a reflection on personal and partial positioning in activity. Therefore, it could accompany professionals - both during university and into working life - in developing awareness around the consequences of informal gender education in terms of inequalities and segregation of skills, knowledges, roles and functions, learning to not be collusive. In this way, for teachers and educators it would become possible to work - from design to intervention - with a gender sensibility inside any specific social and historical, formal and non-formal context. This could also enable a better identification of opportunities and risks offered by informal education, the promotion of intergenerational and intercultural dialogue, and finally a new gender order, fairer and more respectful towards differences. 
This challenge, in Italy, has to face some contextual limits: the lack of national investments towards the implementation of gender intentional education; the fragmentation of gender-related educational projects; the low consideration and sometimes indifference towards the best practices among the educational projects or services implemented in the public and private spheres; and the scarce use of gender-sensitive processual and evaluative indicators.

Furthermore, pedagogical research about gender is suffering too. Beside the absence of economical support at a governmental level (Leonelli 2011b), gender studies are still marginalized in the pedagogical field and the growing literature about gender and education remains unknown among professionals. This situation limits the possibilities of research and intervention that the social scenario could informally offer.

In spite of these uncomfortable conditions, pedagogical research should continue to combine its speculative aims and transformative vocation prompting and promoting new opportunities, without considering gender as a general topic among the many, but as an epistemological heritage which is crucial to understand and act into the current complexity.

\section{References}

Acerbi, Carla, and Marialisa Rizzo. 2016. Pedagogia dell'oratorio. Criticità e prospettive educative. Milano: FrancoAngeli.

Albanesi, Cinzia, and Silvia Lorenzini. 2011. Femmine e maschi nei discorsi tra compagni di classe. Il focus group nella ricerca sul genere in adolescenza. Bologna: Clueb.

Ambrosini, Maurizio. 2011. Sociologia delle Migrazioni. Bologna: Il Mulino.

Antonelli, Francesco, Giada Sarra, and Roberta Sorrentino. 2013. Il sesso mancante nell'università italiana. Available at http://www.ingenere.it/articoli/il-sesso-mancante-nelluniversit-italiana [accessed May 25, 2017].

Berry, John W., Jean S. Phinney, David L. Sam, and Paul Vedder. 2006. «Immigrant Youth: Acculturation, Identity, and Adaptation». Applied Psychology 55 (3): 303-332. DOI: https://doi.org/10.1111/j.1464-0597.2006.00256.x

Brambilla, Lisa. 2016. Divenir donne. L'educazione sociale di genere. Pisa: Edizioni ETS.

Buccoliero, Elena. 2012. «Adolescenti straniere in cerca di tutela». Minorigiustizia 2: 24-30.

Butler, Judith. 1999. Gender trouble. Feminism and the Subversion of Identity. London: Routledge.

Cagnolati, Antonella, Franca Pinto Minerva, and Simonetta Ulivieri. 2013. Le frontiere del corpo. Mutamenti e metamorfosi. Pisa: Edizioni ETS.

Callari Galli, Matilde. 1988. «I sottili percorsi dell'educazione ai ruoli sessuali». Collection de l'École française de Rome 104 (1): 109-122. Available at http://www.persee.fr/doc/ efr_0000-0000_1988_act_104_1_3269

Cambi, Franco. 2009. Pedagogie critiche in Europa. Frontiere e modelli. Roma: Carocci.

Campani, Giovanna. 2010. Genere e globalizzazione. Pisa: ETS.

Castles, Stephen, Hein de Haas, and Mark J. Miller. 2013. The age of migration: international population movements in the modern world. London: Palgrave MacMillan.

Catarci, Marco. 2013. Le forme sociali dell'educazione. Servizi, territori, società. Milano: Franco Angeli. 
Collins, Patricia Hill, and Sirma Bilge. 2016. Intersectionality. Cambridge: Polity.

Crivellaro, Francesca et al. 2013. Generi in relazione: scuole, servizi educativi $0 / 6$ e famiglie in Emilia Romagna. Napoli: Loffredo.

Crul, Maurice, Jens Schneider, and Frans Lelie. 2013. Super-diversity: A new perspective on integration. Amsterdam: VU University Press. Available at https://research.vu.nl/ws/ portalfiles/portal/898459

De Luigi, Nicola, and Laura Gobbi. 2010. Giovani e genere. L'immaginario degli studenti sammarinesi. Roma: Carocci.

Feliciano, Cynthia, and Ruben G. Rumbaut. 2005. «Gendered paths: Educational and occupational expectations and outcomes among adult children of immigrants». Ethnic and Racial Studies 28 (6): 1087-1118. DOI: https://doi.org/10.1080/01419870500224406

Formenti, Laura. 2003. «Copioni familiari e storie tramandate: la trasmissione intergenerazionale dell'identità di genere». In Vivencia. Conoscere la vita da una generazione all'altra, edited by Sandro Bellassai et al., 51-72. Torino: Rosenberg \& Sellier.

Gamberi, Cristina, Maria Agnese Maio, and Giulia Selmi. 2010. Educare al Genere. Riflessioni e strumenti per articolare la complessità. Roma: Carocci.

Granata, Anna. 2015. Diciottenni senza confini. Il capitale interculturale d'Italia. Roma: Carocci.

Guerrini, Valentina. 2017. Educazione e differenza di genere. Una ricerca nella scuola primaria. Pisa: Edizioni ETS.

Hopkins, Peter, and Rachel Pain. 2007. «Geographies of age: Thinking relationally». Area 39 (3): 287-294. DOI: https://doi.org/10.1111/j.1475-4762.2007.00750.x

Kehily, Mary Jane. 2008. «Taking centre stage? Girlhood and the contradictions of femininity across three generations». Girlhood Studies 1 (2): 51-71. DOI: https://doi.org/10.3167/ ghs.2008.010204

Leccardi, Carmen. 2002. Tra i generi. Rileggendo le differenze di genere, di generazione, di orientamento sessuale. Milano: Guerini.

Leonelli, Silvia. 2011a. «La pedagogia di genere in Italia: dall'uguaglianza alla complessificazione». Ricerche di Pedagogia e Didattica 6 (1). DOI: https://doi.org/10.6092/ issn.1970-2221/2237

Leonelli, Silvia. 2011b. «Educare alla costruzione dell'identità di genere in adolescenza. Studi e ricerche nel cotesto italiano». In Femmine e maschi nei discorsi tra compagni di classe. Il focus group nella ricerca sul genere in adolescenza, edited by Cinzia Albanesi and Stefania Lorenzini, 34-61. Bologna: CLUEB.

Mezirow, John. 1991. Transformative Dimension of Adult Learning. San Francisco: Jossey Bass. Murgia, Michela. 2011. Ave Mary. E la chiesa inventò la donna. Torino: Einaudi.

Okin, Susan M. et al. 1999. Is Multiculturalism Bad for Women? Princeton, NJ: Princeton University Press

Padoan, Ivana, and Maria Sangiuliano. 2008. Educare con differenza. Modelli educative e pratiche formative. Torino: Rosenberg \& Sellier.

Palmieri, Cristina. 2012. Crisi sociale e disagio educativo. Spunti di un ricerca pedagogica. Milano: FrancoAngeli.

Papucci, Maria Giovanna. 2010. «Dalla pedagogia della differenza alla progettazione di buone pratiche nella scuola». In Donne, famiglia, famiglie, edited by Mariagrazia Contini and Simonetta Ulivieri, 207-220. Milano: Guerini.

Pasolini, Pier Paolo.1976. Lettere luterane. Il progresso come falso progresso. Torino: Einaudi.

Pyke, Karen, and Denise Johnson. 2003. «Asian American Women and Racialized Femininities: 'doing' Gender across Cultural Worlds». Gender \& Society 17 (1): 33-53. DOI: https://doi.org/10.1177/0891243202238977 
Reggio, Piergiorgio, and Milena Santerini. 2014. Le competenze interculturali nel lavoro educativo. Roma: Carocci.

Risman, Barbara J. 2004. «Gender as a social structure. Theory wrestling with activism». Gender and Society 18 (4): 429-450. DOI: https://doi.org/10.1177/0891243204265349

Saraceno, Chiara and Manuela Naldini. 2013. Sociologia della famiglia. Bologna: Il Mulino.

Scott, Joan W. 1986. «Gender: A Useful Category of Historical Analysis». The American Historical Review 91 (5): 1053-1075. DOI: https://doi.org/10.2307/1864376

Showunmi, Victoria. 2015. «Suffering in silence: Black British Young Women and their Well-being». Available at www.academia.edu/16100459 [accessed Sept 1, 2017].

Simone, Anna. 2011. Sessismo democratico. L'uso strumentale delle donne nel neoliberismo. Milano-Udine: Mimesis.

Tarrant, Anna. 2010. "Constructing a social geography of grandparenthood: A new focus for intergenerationality». Area 42 (2): 190-197. DOI: https://doi.org/10.1111/ j.1475-4762.2009.00920.x

Tramma, Sergio. 2009. Che cos'è l'educazione informale. Roma: Carocci.

Tramma, Sergio. 2015. Pedagogia della contemporaneità. Educare al tempo della crisi. Roma: Carocci.

Ulivieri, Simonetta. 2001. «Genere e formazione scolastica nell'Italia del Novecento.» In Con voce diversa. Pedagogia e differenza sessuale e di genere, edited by Duccio Demetrio et. al., 13-42. Milano: Guerini.

Ulivieri, Simonetta. 2014. Corpi violati. Condizionamenti educative e violenze di genere. Milano: FrancoAngeli.

UNESCO-UNEVOC. 2013. «Promoting learning for the world of work.» Available at http:// www.unevoc.unesco.org/go.php?q=Informal\%20learning [accessed September 1, 2017].

Volpato, Chiara. 2013. Psicosociologia del maschilismo. Roma-Bari: Laterza.

West, Candace, and Don H. Zimmerman. 1987. «Doing gender». Gender and Society 1 (2): 125-151. DOI: https://doi.org/10.1177/0891243287001002002

Lisa Brambilla. Research fellow at the Department of Human Sciences for Education «Riccardo Massa», University of Milano-Bicocca. She holds a PhD in Human Sciences at the University of Milano-Bicocca and a Diploma-certificate course in Femicide and Violence Against Women at the University of Firenze. She worked in projects concerning measures aimed at fighting trafficking in human being and women sexual exploitation. Publications: «Divenir donne. L'educazione sociale di genere» (ETS, 2016).

Electronic address: lisa.brambilla@unimib.it

Giulia Pozzebon. PhD student at the Department of Human Sciences for Education «Riccardo Massa», University of Milano-Bicocca. She is working to a research project titled «Daughters of Immigration. Mixed biographies among gender-based and intercultural dynamics», concerning the biographies of girls with a migration background and their relationships with the Italian educational system. She worked as educator in social services for Italian and migrant women victims of violence or sexual exploitation.

Electronic address: giulia.pozzebon@unimib.it 
Marialisa Rizzo. PhD student at the Department of Human Sciences for Education «Riccardo Massa», University of Milano-Bicocca. She is working to a research project titled «Educational feminine paths and generational passages. A qualitative research with three generations of women, who have an Apulian origin and live in Milan or in its hinterland». She worked as educator in social services for adolescents. Publications (with Carla Acerbi): «Pedagogia dell'oratorio. Criticità e prospettive educative» (FrancoAngeli, 2016).

Electronic address: m.rizzo8@campus.unimib.it

Article received on 31st of May, 2017, and accepted for publication on 31st of October, 2017. 